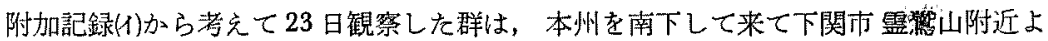
り関門海峡を渡り閒司市砂利山を経て風師山一戸ノ上山一足立山と山伝々に南下してい ったものと思われる。

さて，ハチクマは每年てのよらに群れて渡るものなのか，あるいは今年でけ何か特別 の状況により群れたものなのか明らかでないが，篗者は标そらく前者であららと思ら。 また每年前記のようなコースを渡っているか否かは今後注意したい。

\title{
Migration of Pernis apivorus observed in northern Kiushiu (Nishida, Satoshi)
}

The flock-migration of birds of prey has only been known in Butastur in Japan. But the writer observed about 1,500 Japanese Honey Buzzards migrating over Mt. Adachi in Kokura Gity on September 23, 1961. On the same day 50 migrating birds were observed over Moji by Mr. Takahashi, and on October 15 the writer also observed 11 at Saganoseki, Ōita Prefecture. These observations suggest its migratory route figured in Fig. 1.

\section{オーストンヤマガラの気候による換羽後の羽色変化 小 島 哲 朗}

緒言

一昨年（1960）10日友人から一羽のオーストンヤマガラを講り受け，その後一年市 まり，東宗において飼育した結果，亜種の気候的条件と羽色との関係に興味ある問題を 認めたので，それにつんて報告する。

測定及び羽色，測定 啮峰 13.5 翼長 85 尾長 54 跗蹠 $20(\mathrm{~mm})$

オーストンヤマガラを手にとって見たのは，はじめてのことである。稀には北海道，

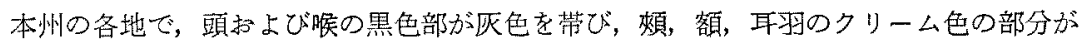
栗色化したものが捕獲されている。それは愛染ヤマガラ或は，弁鹿ヤマかラと呼ばれて レた。このオーストンヤマガラは弁辰ヤマガラと同じく頭及び喉の黑色部が背と同じオ リーブ弗色をおびていた。しかし上記測定の結果でもオーストンヤマガラであるととは 明らかである。

\section{飼 育 経 過}

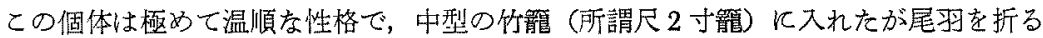

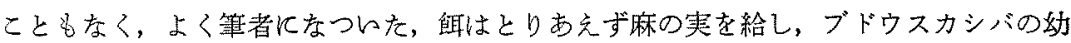
虫 (エビッ゙ル虫), クロスジキンノメイガの幼虫（等），ゴミムシダマシの奻虫（ミー

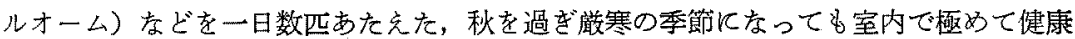
を保ち，無事越冬した。

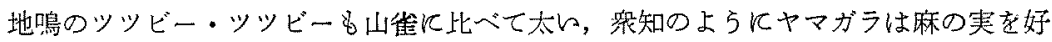




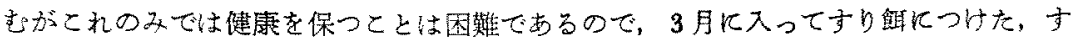
り触は所謂五分慨にュデ王子の黄味 1 個の 10 分の 1 在どを每日すり込んですた充た。 4

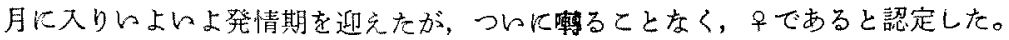

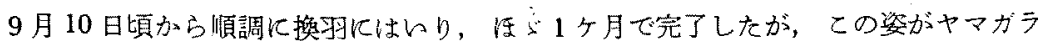
とまったく同色に志った，即ち顔面の腹部と同じ栗色の部分はすべてクリーム色と度り

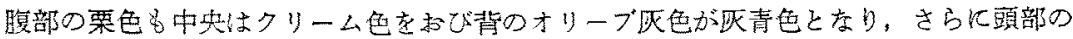

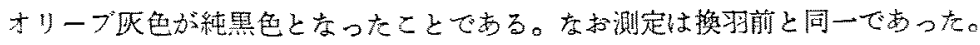

結政

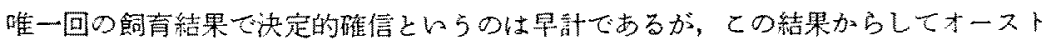

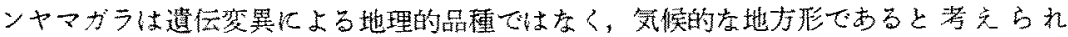

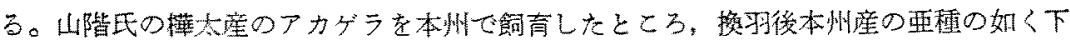

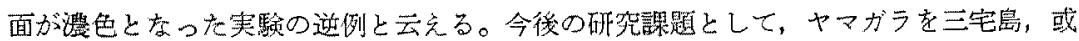

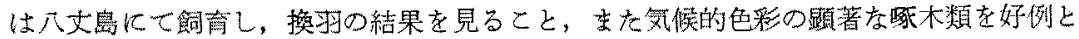
して光線，温度，湿度などの処理によって羽色，色萦，成長などの奏質を検討するなど

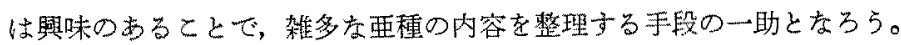

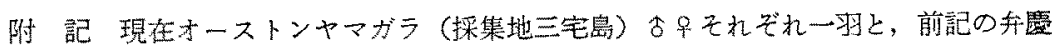

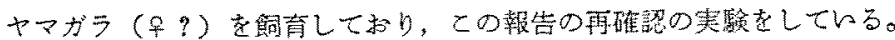

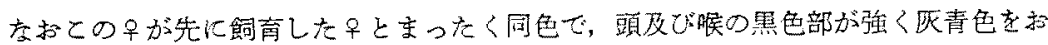
び、僄とんど背と同色でする。

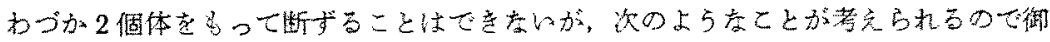

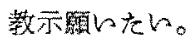

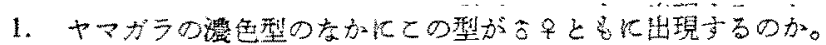

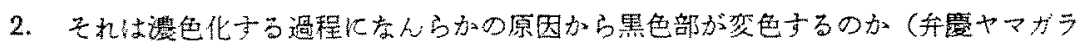

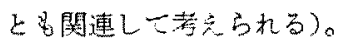

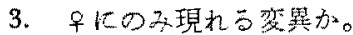

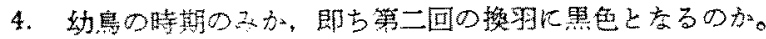

An example of plumage colour change after moult by climatic displacemeut in a Varied Tit (Kojima, Testuro)

A female Owstons' Varied Tit Parus varius owstoni, a dark race of Seven Is. of Izu had been kept by the author in Tokyo from October. In next September this bird moulted its plumage and acquired an entirely different colour which was almost exactly copious to the mainland race $P$. v. varius

The racial colour pattern in this species is therefore entirely climatic (though based only on an example). The measurements remained unchanged. 